\section{Estudo \\ CoDebate}

em Testão

Planejamento
Revista Estudo \& Debate, Lajeado, v. 25, n. 1, 2018. ISSN 1983-036X

DOI: http://dx.doi.org/10.22410/issn.1983-036X.v25i1a2018.1437

\title{
A IMPORTÂNCIA SOCIOECONÔMICA DA PREVIDÊNCIA RURAL PARA O NORDESTE NO DEBATE AMPLO DA SEGURIDADE SOCIAL
}

\author{
Thayse Andrezza Oliveira Do Bu리 , Thaís Marculino da Silva ${ }^{2}$, Ricardo Schmidt Filho ${ }^{3}$
}

\begin{abstract}
Resumo: Desde a década de 1990, a Previdência Social do Brasil, tem sido cenário de polêmicas e divergentes discussóes entre especialistas. De um lado, alguns alegam a insustentabilidade financeira da Previdência Social, em decorrência do envelhecimento populacional e a concessáo de aposentadoria por idade, principalmente no campo, sem ter havido a contrapartida de contribuição. Por outro lado, há os que alicerçados na Constituição Federal de 1988 apontem as falácias em torno da tese da existência de déficit na Previdência. Posto isto, utilizando-se da pesquisa bibliográfica e documental (Associação Brasileira de Auditores Ficais da União ANFIP; Instituto Brasileiro de Geografia e Estatística - IBGE; Ministério da Previdência Social - MPS), o estudo em tela tem como objetivo geral analisar a importância socioeconômica da Previdência Rural Brasileira, com ênfase no Nordeste do país. Como consideraçóes constata-se a importância socioeconômica da aposentadoria rural, especialmente, no Nordeste do Brasil, não só para reduzir o nível de pobreza e desigualdade de renda, mas também como um seguro agrícola, sendo mais importante para os municípios do Nordeste do que o Fundo de Participação dos Municípios.
\end{abstract}

Palavras-chave: Constituição Federal de 1988. Previdência rural. Importância socioeconômica.

\section{THE SOCIOECONOMIC IMPORTANCE OF NORTHEAST RURAL PREVENTION IN THE WIDER DEBATE OF SOCIAL SECURITY}

\begin{abstract}
Since the 1990s, Brazilian Social Security has been a scenario for controversy and divergent discussions among experts. On one hand, some of them argue the financial unsustainability of the Social Security as a result of demographic aging and the concession of retirement by age, especially in the rural area, without having been the contribution counterpart. On the other hand, there are those that grounded in the Constitution of 1988 point out the fallacies around the thesis of the existence of a deficit in Social Security. Being that said, based on bibliographic research and documentary research (Brazilian Association of Federal Auditors - BAFA; Brazilian
\end{abstract}

1 Servidora pública estatutária do governo do estado da Paraíba; professora do PRONATEC - PB e mestranda em Desenvolvimento Regional pela Universidade Estadual da Paraíba - UEPB (thayseandrezza@hotmail.com)

2 Professora substituta, Auxiliar, Nível 1, da UFCG/UAECON e mestranda em Recursos Naturais pela Universidade Federal de Campina Grande -UFCG (thaismarculino@hotmail.com)

3 Dr. Professor da Unidade Acadêmica de Economia - UFCG (rschmidtfilho@hotmail.com) 
Institute of Geography and Statistics - BIGS; Ministry of Social Security - MSS), this study aims to analyze the socio-economic importance of the Brazilian Rural Social Security, with emphasis on the Northeast of the country. As considerations it is concluded the socio-economic importance of rural retirement, especially in the Northeast of Brazil, not only to reduce the level of poverty and income inequality, but also as an agricultural insurance being more important for Northeast municipalities than the Municipalities Participation Fund.

Keywords: Federal Constitution of 1988. Rural Security. Socioeconomic importance.

\section{INTRODUÇÁO}

Desde 2005, com o escândalo do "Mensalão", e mais recentemente, com crise econômica (desde 2008), com o impeachment de a Presidente Dilma, escândalo de corrupção na Petrobrás, dentre outros casos; o Brasil vive um cenário político e econômico crescentemente turbulento. Inúmeras denúncias envolvendo corrupção entre políticos e grandes empresas do país, tem deixado os agentes econômicos receosos, deteriorando, ainda mais, os diversos indicadores macroeconômicos do país. Por exemplo, tem-se visto: dificuldades no setor produtivo nacional, e, portanto, reduçáo do Produto Interno Bruto (PIB), o crescimento do desemprego, redução no consumo, a queda na renda do trabalho e, por conseguinte, o aumento das desigualdades sociais.

E nesse cenário tem surgido dois fenômenos: insatisfação e descrença da população brasileira no poder público e, de outro lado, tem surgido a defesa, por parte de alguns especialistas e agentes políticos, da necessidade imediata de promover políticas fiscais restritivas e reformas trabalhista e previdenciária. Em outras palavras, um ajuste fiscal no âmbito das políticas públicas sociais.

Contudo, desde 2014, verifica-se a propagação maior da necessidade de promover uma reforma da Previdência Social Brasileira na direção de redução dos direitos dos beneficiários e/ou elevação do tempo de contribuição.

Embora seja um debate tấo recente, desde a década de 1990, a Previdência Social do país tem sido cenário de polêmicas e divergentes discussóes entre especialistas. De um lado, tem os que defendem a tese de insustentabilidade financeira da Previdência Social Brasileira a longo prazo, em decorrência do envelhecimento populacional e da concessão de benefícios sem a contrapartida de contribuição, como é o caso da aposentadoria rural. Desse modo, defendem a realização de reformas, na direção da substituição do regime de repartição simples para um regime de capitalização (MARQUES, 2007).

Por outro lado, há os especialistas que, alicerçados na Constituição Federal de 1988, apresentem falácias em torno da tese de déficit. Argumentando que o propagado déficit é resultado de um cálculo que não considera as receitas que devem ser destinadas à Previdência Social, como preconiza a Constituição de 1988 (Art. 195). Ou seja, não leva em consideração a Contribuição para Financiamento da Seguridade Social (COFINS); a Contribuição Social sobre o Lucro Líquido (CSLL); parte da receita proveniente dos concursos de prognósticos (mega-sena, sena, loteria esportiva e outros) e a extinta Contribuiçấo Provisória sobre Movimentação Financeira (CPMF).

Osque sustentam a tese de insustentabilidade financeira da Previdência Social Brasileira apresentam a concessão de aposentadorias rurais, como um dos fatores que acarretam o 
déficit previdenciário do país; justamente, porque a maior parte das aposentadorias rurais é concedida por idade, isto é, sem a contrapartida da contribuição.

Contudo, para o poder público, a concessão de aposentadorias por idade é interpretada como um instrumento compensatório, para promover o desenvolvimento rural, sendo uma solução para os agricultores que não conseguiram se modernizar tecnologicamente, nem se integrar ao conjunto da economia através da indústria, comércio e serviços.

Por outro lado, como explica Delgado e Cardoso Júnior (2000), foi percebido que o benefício rural cumpre não só a função precípua de seguro previdenciário, isto é, operando dentro do âmbito original que orientou sua concepção, mas também, atende de modo fundamental, ainda que indiretamente, uma função de seguro agrícola, uma vez que serve para garantir a subsistência familiar e até permite financiar a pequena produção das unidades familiares.

Esse trabalho tem como objetivo geral analisar a importância socioeconômica da Previdência Rural Brasileira para a região Nordeste do país. Para tanto, o trabalho se utilizou da pesquisa bibliográfica e da pesquisa documental. Portanto, na primeira seção recorre-se à literatura sobre a previdência rural, no âmbito legal, para discutir sobre os avanços na legislação previdenciária brasileira para os moradores do meio rural. Porém, considerou-se necessário entender o que estava por trás dessas conquistas e, na segunda seção buscou-se compreender o processo e o contexto de lutas pelos direitos apresentados na primeira parte do trabalho.

Por sua vez, a terceira seção dedica atenção a verificar a importância socioeconômica da Previdência Rural para a região Nordeste do país. Para tanto, recorre-se à análise dos relatórios técnicos da Associação Brasileira de Auditores Ficais da União (ANFIP) e os dados estatísticos disponibilizados pelo Ministério da Previdência Social e pelo Instituto Brasileiro de Geografia e Estatística. Nosso foco foi fazer uma análise de comparação entre a região Nordeste, o Sul e o Brasil, justamente, porque, no cenário político recente, tanto nas mídias convencionais, como nas redes sociais, percebe-se que ainda persiste que o Brasil "sustenta" a região Nordeste, e no âmbito da Previdência Social, o maior argumento é que tal região é a grande responsável pelo déficit na Previdência, por ser a maior receptora de aposentadorias por idade. Por fim, apresentam-se as conclusóes.

\section{AS CONQUISTAS LEGAIS NA PREVIDÊNCIA RURAL DENTRO DO CONTEXTO AMPLO DA SEGURIDADE SOCIAL}

A literatura sobre a proteção social considera que no Brasil, o marco do surgimento inicial da previdência é a Lei Eloy Chaves, a partir do Decreto Legislativo no 4.682, de 24 de janeiro de 1923, que criou em cada uma das empresas de estradas de ferro existentes no País, na época, uma Caixa de Aposentadorias e Pensóes (CAPs) para os respectivos empregados (SERRA \& GURGEL, 2011). Porém, no contexto de benefícios para o trabalhador rural, somente quarenta anos depois, a partir de 1963, com a criação do Estatuto do Trabalhador Rural, pela Lei no 4.214, de 2 de março de 1963, é que se pode dizer que os trabalhadores rurais teriam sido incluídos, no âmbito normativo, no sistema previdenciário do país (GUIMARÁES, 2009). 
Porém, cabe elucidar que o Estatuto do Trabalhador Rural não chegou a ser regulamentado. Logo, "[...] mais uma vez, os camponeses ficaram desprotegidos, embora com lei protegendo-os" (GUIMARÃES, 2009, p. 2). Apenas com o Decreto-lei no 276, de 28 de fevereiro de 1967, que instituiu o Fundo de Assistência e Previdência do Trabalhador Rural (FUNRURAL) - o que já previa o artigo 158 do Estatuto do Trabalhador Rural, é que o homem do campo, pode, na prática, ter alguma proteção. Contudo, como destaca o autor supracitado:

O Decreto-lei $n^{\circ}$ 276/67, cuidou mais da criação do Funrural, com maior enfoque na área da saúde do trabalhador rural do que na previdência social rural propriamente dita. Sobre o aspecto previdenciário, o mencionado decreto, como visto, apenas elencou quem seriam os beneficiários, como segurados e como dependentes da Previdência em alusão (GUIMARÃES, 2009, p. 2).

Contudo, a partir da década de 1970, ocorreram grandes avanços na legislação previdenciária para o morador do rural, como destaca Gentil (2006, p.106):

1) a criação do Programa de Integração Social (PIS), em 1970; 2) a instituição do Programa de Assistência ao Trabalhador Rural (PRORURAL), em 1971, com execução a cargo do Fundo de Assistência ao Trabalhador Rural (FUNRURAL), incluindo os trabalhadores rurais na previdência - com um plano de benefícios muito inferior, pois a aposentadoria correspondia, então, a 50\% do salário mínimo - e estabelecendo uma solidariedade formal entre a área urbana e rural através do custeio dos benefícios - uma vez que não havia contribuição direta; 3) a inclusão dos empregados domésticos, com a Lei no 5.859, de 1972; e, 4) a inclusão dos trabalhadores autônomos, com a Lei no 5.890, de 1973 (GENTIL, 2006, p.106).

Contudo, persistia a exclusão das camadas mais pobres da população que não contribuíam para a previdência social e ficavam sem nenhum acesso a serviços médicos, agravando assim, ainda mais, a desigualdade. Assim, o, " [...] setor privado servia aos ricos, os planos eram para grupos seletos de assalariados e classes médias, os serviços públicos para pagantes da previdência e a 'caridade' para os pobres" (GENTIL, 2006, p.106).

Em 1977, a Lei no 6.439, criou o Sistema Nacional de Previdência e Assistência Social (SINPAS), com o objetivo de integrar as funções de concessão e manutenção de benefícios, prestação de serviços, custeio de atividades e programas e gestáo administrativa, financeira e patrimonial da previdência e assistência social (MIRANDA, 2010; LEÔNCIO, 2011).

Para o cumprimento desse objetivo, o Instituto Nacional de Previdência Social INPS foi desmembrado em três órgãos, a saber: I- O próprio INPS, com a função de arcar com os benefícios previdenciários e assistenciais; II- O INAMPS (Instituto Nacional de Assistência Médica da Previdência Social) que tinha a função de administrar o sistema de saúde; e, III- O IAPAS (Instituto de Administração da Previdência e Assistência Social) 
que tinha a função de administrar a arrecadação de recursos para o INPS e INAMPS ${ }^{4}$ (MIRANDA, 2010; LEÔNCIO, 2011).

Nesse contexto, verifica-se também, a extinção do FUNRURAL, ficando, desde então, com o INPS a responsabilidade de conceder e manter os benefícios dos trabalhadores rurais. (SERRA; GURGEL, 2011).

Com a Constituição de 1988, os trabalhadores rurais passaram a receber aposentadoria de um salário mínimo, independentemente de contribuição, ampliando a cobertura inaugurada no Regime Militar, com o FUNRURAL, no qual, segmentos da população, como os deficientes físicos, também passaram a ter uma remuneração mensal e vitalícia. Além dos trabalhadores urbanos (sob determinadas condiçōes), que também passaram a ter cobertura pela Loas (Lei Orgânica de Assistência Social) ${ }^{5}$, como destaca Passarinho (2007).

De modo geral, a Constituição de 1988 é considerada um marco jurídico-político do processo de redemocratização do país. No âmbito da previdência social, a inclusão de um capítulo, sobre a seguridade social foi o mais importante esforço de modernização da história da Previdência Social Brasileira. Assim, no contexto nacional, a Previdência Social é parte de um sistema mais abrangente, no caso, a Seguridade Social.

Conforme Miranda (2010), entende-se que a seguridade social é um serviço público não só pela natureza jurídica dos organismos que a administram, mas também, porque a solução das necessidades que busca amenizar, é dada pela coletividade e pela solidariedade. Em síntese, a seguridade social tem como preceito básico a vinculação de sua administração ao Estado, por motivos que ultrapassam a esfera jurídica, como o autor expôs. E mais, cabe lembrar que a Seguridade Social é um sistema de cobertura de contingências sociais destinado a todos os que se encontram em necessidade; não restringe benefícios, nem a contribuintes nem a trabalhadores; e estende a noção de risco social, associando-a não apenas à perda ou redução da capacidade laborativa, mas também, às situaçóes em que a insuficiência de renda fragiliza a vida do cidadão.

Portanto, como aponta Passarinho (2007, p.38): "A constituição de 1988 consagrou a ideia de que deveríamos ter um Estado promotor da cidadania e dos direitos sociais". E acrescenta que "o conceito de seguridade social, segundo o qual a previdência - ao lado da saúde e da assistência social - deve constituir-se em um direito de todo e qualquer cidadáo".

Ademais, a Constituição de 1988 inovou ao reduzir a dependência da receita previdenciária às oscilaçôes do ciclo econômico, estabelecendo a tributação sobre o faturamento e o lucro, porque são bases de cálculo mais estáveis para as contribuiçóes sociais que a folha salarial. Assim, no artigo 195 da Constituição Federal de 1988, trata do orçamento próprio e exclusivo da seguridade social, onde cria fontes de receitas específicas para o financiamento dessas despesas (GENTIL, 2007; MARQUES, 2007).

4 No que se refere ao SINPAS, cabe destacar que assumiu novos encargos sem ter a provisão adequada de recursos para manter o equilíbrio do sistema.

5 Para mais detalhes, veja Gentil (2006). 
Neste contexto, são as principais fontes de receita (vinculadas estritamente às despesas da seguridade social): a Contribuição para Financiamento da Seguridade Social (COFINS); a Contribuição Social sobre o Lucro Líquido (CSLL); parte da receita proveniente dos concursos de prognósticos (mega-sena, sena, loteria esportiva e outros) e a extinta Contribuição Provisória sobre Movimentação Financeira (CPMF), até sua extinção em 2007 (GENTIL, 2007; MARQUES, 2007).

No Brasil, a previdência social divide-se em dois sistemas (usualmente chamados de Regime), ao qual fazem parte de um sistema de seguridade universal para todos os cidadãos (RGPS) e um sistema especial para o funcionalismo público (RPPS), assim: i) Regime Geral de Previdência Social (RGPS) e ii) Regimes Próprios de Previdência dos servidores (RPPS). O primeiro compreende a iniciativa privada no seu total (empregados, sócios de empresas, domésticos, autônomos, facultativos, dentre outros) e, é de responsabilidade do INSS (Instituto Nacional de Seguridade Social) que foi criado em 1990, com a fusão do INPS e IAPAS. Já o segundo regime, destina-se aos servidores públicos efetivos dos entes federativos e está a cargo do respectivo ente da federação, que pode, para administrá-lo, instituir entidade autárquica própria. Os regimes dos servidores públicos são caracterizados por serem regidos pelos estatutos dos diferentes órgãos da União dos estados e dos municípios, ou seja, a regulamentação desses sistemas previdenciários varia dependendo da classe profissional, da área de atuação; entre muitos outros pontos (MIRANDA, 2010; PASSARINHO, 2007).

Nesse cenário, a Previdência Social Brasileira é financiada por toda a sociedade (direta e indiretamente), através de recursos das três esferas do governo e da contribuição dos empregadores e empregados, o seu sistema é tripartite (contribuintes, empregadores e Estado). Sendo o pagamento dos benefícios dos aposentados feito com o montante arrecadado dos contribuintes da ativa, sistema este, denominado de repartição simples (FERREIRA, 2008).

Entretanto, como já mencionado, imediatamente após essas conquistas, já em 1989 emergiu um polêmico e controverso debate em prol de reformas na previdência com o argumento da tese de insustentabilidade financeira a longo prazo, devido a "gama" de benefícios e direitos sendo concedidos pela Carta Magna. Desse modo, surge o discurso do déficit crescente na previdência social brasileira, em decorrência do envelhecimento populacional e da concessão de aposentadoria rural no valor de um salário mínimo, inclusive, àqueles que não contribuíram. Portanto, os que sustentam a tese da insustentabilidade alegam que, assim, gerou um desequilíbrio crescente atuarial.

Opondo-se a tese da insustentabilidade na Previdência, existe a corrente teórica que afirma não haver déficit na previdência e que ela é, predominante, superavitária. Em outros termos, segundo Gentil (2006), enquanto a corrente ortodoxa (os conservadores) observa o resultado previdenciário, nos dados disponibilizados pelo governo, a corrente heterodoxa (os progressistas) leva em consideração o saldo operacional, por este, considerar todas as receitas que devem ser destinadas à previdência, e a seguridade social como um todo, conforme a Constituição de 1988 estabelece.

Nesse sentido, como expóe Brasil (2013; 2016), o resultado previdenciário é oriundo do seguinte cálculo: Saldo previdenciário = Arrecadação Líquida- Benefícios do RGPS; 
onde: Arrecadaçáo Líquida= recebimentos próprios - transferências a terceiros - taxa de administração sobre outras entidades ${ }^{6}$.

$\mathrm{Na}$ realidade, esse cálculo não leva em consideração todas as receitas que devem ser destinadas à previdência social, como preconiza a Constituição de 1988 (Art. 195), pois deixa de contabilizar recursos como a CONFINS, a CPMF, a CSLL e a receita de concursos prognósticos (GENTIL, 2006).

Desse modo, o que deveria ser analisado seria o saldo operacional, que, conforme explica Brasil (2013; 2016) é: Saldo operacional = Recebimentos (Recursos próprios + Transferências da Uniáo) - Pagamentos .

Onde: Recursos próprios compreendem a arrecadação bancária, os rendimentos de aplicaçóes financeiras e outros. E o valor das Transferências da União é formado por arrecadação SIMPLES, COFINS, CSSL, concursos prognósticos e outros. E na arrecadação bancária estão incluídas as contribuições sociais de terceiros (SENAI, SESI, SESC etc.). Pagamentos - valor dos recursos destinados ao pagamento de benefícios, à administração do sistema e às transferências a terceiros.

O cerne do discurso do déficitse dá primeiro, em decorrência da Leide Responsabilidade Fiscal (LRF), criada em 2000, desligar a Previdência Social do Orçamento de Seguridade Social. E segundo, por passar a considerar as fontes de recursos que foi citado anteriormente como componentes do Orçamento Fiscal Geral. Dessa forma, aparentemente, a Previdência perde suas principais fontes de receita, ao mesmo tempo em que ganha uma nova rubrica "Transferências da União", que registra o montante do repasse de apenas uma parte da receita que antes era própria (GENTIL, 2006).

Esta mudança, além de ferir de várias maneiras a concepção de seguridade social estabelecida na Carta Magna de 1988, permitiu ainda, a afirmação de que as transferências da Uniâo têm que ser realizadas para cobrir um suposto déficit na Previdência. Delegando assim, a "culpa" ao envelhecimento populacional e à aposentadoria rural, justamente porque, a maioria dos beneficiários do rural não contribuíram para receber o benefício, como trataremos no tópico 3. Logo, segundo a tese dos que defendem um déficit na previdência se não houve contribuição, não deveria haver concessão de benefício, sendo estes, considerados com alvos apenas da assistência social e jamais no valor de um salário mínimo.

Em contraposição, a postura do poder público, ao implantar a concessão de aposentadorias por idade, é de que ela seria um instrumento compensatório, vista como a solução para os agricultores que não conseguiam se modernizar tecnologicamente nem integrar-se ao conjunto da economia através da indústria, comércio e serviços. Por muito tempo, essa tem sido a visão para promover o desenvolvimento rural, ou seja, sendo associado ao "conjunto de açóes do Estado e dos organismos internacionais destinadas às intervençóes

6 Recebimentos próprios é o somatório da arrecadação bancária e dos rendimentos de aplicaçôes financeiras e outros. Na arrecadação bancária estão incluídas as contribuições sociais de terceiros (SENAI, SESI, SESC etc.). Por isso, devemos deduzir as transferências a terceiros o valor repassado das contribuiçóes sociais às respectivas entidades (SENAI, SENAR, SESC, SESI). 
nas regióes rurais pobres que não conseguiam se integrar ao processo de modernização agrícola via substituição de fatores de produção considerados atrasados" (SCHNEIDER, 2010, p. 511).

De modo geral, os direitos sociais expressos na Constituição de 1988 são reflexos do momento histórico que se seguiu ao desmoronamento do regime militar brasileiro e que resultou num movimento de liberação de demandas sociais sufocadas por vinte anos de ditadura. Logo, os avanços conquistados no espaço rural, principalmente, no benefício dos mais pobres do campo, foram através de lutas de movimentos sociais como: as Ligas Camponesas, o Movimento dos Sem-Terra (MST), o Movimento do Atingidos por Barragens (MAB) e tantos outros que surgem ao longo da exploração do Brasil. Por seu turno, com todas essas pressóes, o Estado tinha que dá a sua contrapartida e atender parte da massa populacional, sobretudo, após a Constituição de 1988.

Neste contexto, com a abertura democrática e mudanças político-institucionais em curso,
os representantes da agricultura familiar alteraram sua postura diante do Estado. As
possibilidades abertas com o debate da constituinte, as negociaçóes para a definiçáo das
Leis Agrícola e Agrária, e a emergência dos Conselhos alteraram a forma de interaçấo entre
a sociedade civil representativa dos agricultores familiares e o Estado. Os representantes
da agricultura passaram a adotar estratégias propositivas e adentraram nas arenas públicas,
propondo e disputando a construçâao das políticas públicas (GRISA; SCHNEIDER, 2015,
p. 25).

Nesse cenário, além de entendermos, no tópico três, os efeitos da previdência rural sob o homem do campo, vamos, antes, compreender o contexto de lutas para essas "vitórias" aqui descritas e, que há muito tempo já querem que sejam suprimidas. Assim, vamos também entender no tópico que se segue as mudanças no caráter ideológico por traz das políticas públicas em prol do desenvolvimento rural. Faz-se importante trazer essa discussão, pois como explica Wanderely (2010, p. 17): “[...] 'rural' não é uma essência, a-histórica, que deva ser reconhecida indistintamente, em todos os lugares e todos os tempos". Contudo, levando em consideração que cada país adota critérios administrativos para definir o que considera como zonas rurais, distintas das áreas urbanas, a autora supracitada acrescenta:

\footnotetext{
Quaisquer que sejam suas formas espaciais e sociais, resultantes das distintas formaçôes históricas, das quais fazem parte, o mundo rural se define por uma dupla característica: a predominância dos espaços naturais sobre os espaços construídos e sua conformação enquanto pequeno grupo social, onde predominam as relaçōes de proximidade e de interconhecimento (WANDERLEY, 2010, p. 20).
}

Portanto, pensar as lutas e conquistas do segmento do rural denominado agricultura familiar ${ }^{7}$, trazendo para o contexto da realidade da nossa regiáo, é fundamental, para que,

7 Como explica Schneider (2010, p. 515): "Por certo, tanto a agricultura familiar como os agricultores que hoje são assim denominados sempre existiram, e não se trata de uma novidade. Mas é mister reconhecer que foi na primeira metade da década de 1990 que esta noção se firmou como uma categoria política, sendo em seguida assimilada por estudiosos e por formuladores de políticas, o que lhe confere atualmente uma extraordinária legitimidade". 
no tópico três, possamos entender os impactos socioeconômicos da previdência rural para o morador do rural, ou seja, é fundamental trazer tal debate, para que além de números "secos", os interpretemos com base no contexto histórico e ideológico.

\section{AGRICULTURA FAMILIAR: AS LUTAS E AS CONQUISTAS DE DIREITOS SOCIAIS}

De acordo com Wanderley (2001) a agricultura familiar tem por característica que a família é proprietária dos meios de produção e também realiza o trabalho produtivo, ou seja, existe uma associação entre família-produção-trabalho.

Nesse sentido, Grisa e Schneider (2015) explicam que: "Historicamente, a agricultura familiar ou 'os pequenos agricultores' - como eram denominados até cerca de duas décadas atrás - sempre estiveram às margens das ações do Estado brasileiro, não raro incrementando sua fragilidade diante das opções de desenvolvimento perseguidas no País".

Até a década de 1980, não havia muitas açôes no campo da proteção social em prol dos trabalhadores rurais. Em outras palavras, como explica Schneider (2010) quando se pensava em promover alguma política pública em prol dos que moravam no rural, pensavase em intervençóes por parte do Estado, de caráter compensatória, na tentativa de trazer "soluçôes" para os pobres do campo, ou seja, para os agricultores que não conseguiam se modernizar tecnologicamente nem se inserir ao conjunto da economia através da indústria, comércio ou serviços.

Nos anos de 1960 e 1970, como explica Silva (2006), o foco das políticas públicas destinadas ao rural brasileiro estava alicerçado no discurso da modernização da agricultura como promessa do progresso. Assim, a modernização seria o uso racional das terras e dos demais recursos produtivos, assegurando: "a produção de alimentos necessários à população, gerar divisas para nossas economias e articular social e economicamente o setor agrícola ao processo geral de desenvolvimento" (WANDERLEY, 2010, p. 22)

Tal postura é resultado da crise, que se iniciou no Brasil, a partir da década de 1930, da estratégia de industrialização por substituição de importaçóes, expressa por dificuldades no abastecimento alimentar interno, aumento da inflação e esgotamento da capacidade de importar bens necessários à industrialização (SILVA, 2006). Merece destaque o fato de que o cenário nacional era favorável após a criação do Sistema Nacional de Crédito Rural (SNCR), em 1965, a partir do qual a concessão de crédito a taxas de juros e condiçóes de pagamento diferenciadas configurou um grande impulso ao setor agropecuário (RAMOS; MARTHA JÚNIOR, 2010).

Contudo, no âmbito do Brasil e de todo o conjunto dos países da América Latina, sob formas e graus distintos, foi o grande proprietário da terra que se beneficiou, das açóes do poder público. Particularmente, no contexto nacional, até 1980, o referencial setorial predominante que orientou as ações do Estado no setor agrícola e pecuário foi a política agrícola ativa, que beneficiou os médios e grandes agricultores, localizados na região sul

8 Conforme pode ser melhor analisado em TAVARES (1992). 
e sudeste do país, produtores de bens direcionados à exportação (WANDERLEY, 2010; GRISA; SCHNEIDER, 2015).

Por sua vez, na década de 1980, graças ao processo de democratização houve um intenso movimento de rearticulação e florescimento de novas organizaçóes na sociedade civil; crescendo assim, a defesa por reforma agrária e políticas e legislação trabalhista diferenciadas para a agricultura familiar, ou seja, passou-se a exigir políticas específicas para a categoria e a participação na sua construção (GRISA; SCHNEIDER, 2014).

As lutas por crédito, por melhoria de preços, por formas de comercialização diferenciadas,
pela implementaçáo da regulamentaçáo constitucional da previdência social rural, por
proteção contra a desregulamentação e a abertura comercial indiscriminada (promovida
no âmbito dos acordos do Mercosul), fizeram a CONTAG (Confederaçáo Nacional
dos Trabalhadores da Agricultura) aliar-se a outros movimentos emergentes, como o
Departamento Nacional dos Trabalhadores Rurais (DNTR), ligado a CUT, que havia sido
criado em 1988. Daí emergiram formas de mobilizaçáo e lutas que produziram grande
impacto político, tais como as Jornadas Nacionais de Luta, logo a seguir transformadas
no Grito da Terra Brasil, movimento anual que persiste até hoje (SCHINEIDER, 2010,
p. 515).

Em concomitância, cresce no final da década de 1980 para 1990 intensas mudanças político-econômicas. Logo, na década de 1990, com o neoliberalismo, ocorre a desestruturação de instrumentos de políticas públicas importantes voltadas para o rural, como a extinção da Empresa Brasileira de Assistência Técnica e Extensão Rural EMBRATER. E nesse período, compreendia-se que o Estado deveria corrigir as "falhas de mercado", combatendo a pobreza rural (GRISA; SCHNEIDER, 2014).

Por outro lado, como destaca o Schneider (2010), somente a partir da década de 1990, é que se verifica uma mudança de enfoque e de entendimento sobre como promover o desenvolvimento rural. $\mathrm{Na}$ qual, das discussóes recentes sobre o desenvolvimento rural, favorecida no período de redemocratização do Brasil, gerou políticas governamentais direcionadas para o crédito para agricultura familiar; a reforma agrária; o apoio aos territórios rurais, o estímulo a açóes afirmativas para mulheres, jovens, aposentados e negros.

Em resposta às pressões oriundas de várias mobilizaçóes sociais, emerge, em 1995, a Política Agrícola Nacional direcionada para os agricultores familiares - PRONAF. Uma política de crédito rural para fortalecer e garantir a produção agrícola dos agricultores, representando o reconhecimento político e institucional do Estado brasileiro à categoria social. Porém, a partir de 1997-98, as políticas para a agricultura familiar aportaram para um novo referencial setorial focado em açóes sociais e assistenciais. Ou seja, as políticas para a agricultura familiar se aproximaram das políticas sociais. Por sua vez, entre 1998 e 2000, surge um conjunto de ações de transferências de renda que contemplam a agricultura familiar, como Bolsa Escola, Alimentação e Auxílio Gás (GRISA; SCHNEIDER, 2015).

Por seu turno, a partir dos anos 2000, no âmbito das relaçóes do Estado com a sociedade civil, ocorreram importantes mudanças. Abriu-se oportunidade para a institucionalização de novas ideias e reivindicações políticas, principalmente, na área dos mercados de segurança alimentar e sustentabilidade. Assim, foi criado o Ministério Extraordinário de Segurança Alimentar e Combate à Fome (MESA) e o Programa de Aquisição de Alimentos e a Política 
de Garantia de Preços Mínimos. Desse modo, como explica Grisa e Schneider (2014, p.38): "Representou a culminância de todo um processo anterior de formulaçóes e práticas na luta contra a fome e pela segurança alimentar e nutricional no Brasil experimentadas por governos e organizaçóes sociais".

Em outras palavras, como explica Grisa e Schneider (2014), ao decorrer desses quase 30 últimos anos no Brasil, ocorreram mudanças importantes no cenário político institucional e nas dinâmicas sociais e o marco inicial destas transformaçóes se deu a partir da promulgação da Constituição de 1988. Vale destacar:

\begin{abstract}
Novas relaçóes entre Estado e sociedade civil foram estabelecidas, espaços de participação foram criados [...] Como protagonista e objeto de muitas destas mudanças destaca-se a agricultura familiar, uma categoria social e política que passou a ser reconhecida pelo Estado brasileiro em meados de 1990 (GRISA; SCHNEIDER, 2015, p.20).
\end{abstract}

Em contraposição ao cenário da década de 1980, como explicam Schneider (2010) e Peterson (2013), a partir dos anos 2000, a agenda de ações do Estado tem sido menos influenciada pelos demandantes diretos das políticas, no caso os agricultores e as populaçóes rurais, do que pelos estudiosos e mediadores.

De modo geral, para o efetivo êxito de uma política pública para "o rural brasileiro" é preciso ouvir os demandantes daquela política, bem como, compreender as particularidades de cada local, as diversas dinâmicas existentes, pois, como já vimos, em consonância com Wanderley (2010), não existe apenas um rural, mas sim, vários rurais, dentro do que se considera área rural.

Por exemplo, no âmbito do Nordeste do Brasil, há particularidades próprias quando falamos intraregionalmente e interegionalmente que, devem ser consideradas, quando pensamos no contexto da elaboraçáo e/ou análise de políticas públicas. Em outras palavras, como explica Galeano (2009, p. 89 apud WANDERLEY, 2010, p. 18): "No Nordeste nem mesmo o progresso é progressista, porque até o progresso está em mãos de poucos proprietários.".

$\mathrm{Na}$ verdade, a situação estrutural de concentração de renda e de terra ${ }^{9}$ e, por conseguinte de pobreza, da região Nordeste se agrava nos períodos de seca no Semiárido Nordestino. Em decorrência disso, tal regiáo sempre foi vista como regiáo problema, onde, muitos dos seus moradores, principalmente durante as décadas de 1960-70, realizaram o êxodo rural para fugir de suas mazelas. Contudo, desde 1980, mudaram-se os debates e olhares para o Semiárido Brasileiro, em especial, o Nordestino; e emergiu a defesa de políticas públicas para a convivência com a região (SILVA, 2006).

Assim, segundo Malvezzi (2007, p 11-12 apud CUNHA; PAULINO, 2014, p. 4- 5):

9 Para maiores informações acerca da estrutura fundiária brasileira e nordestina, bem como sobre a participação das regióes nos totais de contratos e no volume de recursos do PRONAF observar Da Silva, Schmidt Filho, Aguiar e Costa (2017). 
A ideia parte de um princípio simples: por que os povos do gelo podem viver bem no gelo, os povos do deserto podem viver bem no deserto, os povos das ilhas podem viver bem nas ilhas e a população da região semi-árida vive mal aqui? É porque aqueles povos desenvolveram culturas de convivência adequadas ao ambiente, adaptaram-se a ele e tornaram viável a vida. No Semi-Árido brasileiro, essa integração de pessoa e natureza não encontrou uma soluçáo adequada, de modo que o ser humano permaneceu sujeito às variaçóes normais do clima regional. O segredo da convivência está em compreender como o clima funciona e adequar-se a ele. Não se trata mais de 'acabar com a seca', mas de adaptar-se de forma inteligente. É preciso interferir no ambiente, é claro, mas respeitando as leis de um ecossistema que, embora frágil, tem riquezas surpreendentes.

Em suma, como explica Silva (2006) e Cunha e Paulino (2014), a intervenção no semiárido, por meio de políticas públicas era de cunho emergencial (e assistencialista) de "socorro" às vítimas da seca. Contudo, desde o surgimento da tese da convivência com a região, verificam-se açóes de caráter mais permanente (porém, não estruturais) ${ }^{10} \mathrm{de}$ combate à seca e seus efeitos, como realização de obras hídricas e políticas governamentais de "modernizaçáo" das atividades produtivas do Semiárido, tornando-as mais resistentes aos efeitos da seca.

Contudo, outra política que tem contribuído para a permanência e, por conseguinte, para a permanência/convivência do morador rural nordestino, tem sido a previdência rural que, como veremos no tópico a seguir, já nos primeiros anos após a Constituição de 1988 já se reconhece e observa sua a importância para esse segmento da população brasileira.

\section{IMPACTOS SOCIOECONÔMICOS DA PREVIDÊNCIA RURAL}

Nessa seção vamos analisar os efeitos socioeconômicos que as conquistas legais, aqui discutidas, especialmente, as trazidas pela Constituição de 1988, trouxeram para o trabalhador rural. De modo geral, já vimos, que, com a Carta Magna, os trabalhadores rurais passaram a receber aposentadoria de um salário mínimo, independentemente de contribuição, ampliando assim, a cobertura inaugurada no Regime Militar com o FUNRURAL; onde, segmentos da população, como os deficientes físicos, também passaram a ter uma remuneração mensal e vitalícia (PASSARINHO, 2007).

Como consequência, conforme observamos no Gráfico 1, observa-se que o número de benefícios pagos pela Previdência Social foi ampliado de R\$11,6 milhóes, em 1988; para R \$ 17,8 milhóes, em 1999, o que representa um incremento de 53,5\% no período. Sendo que, os benefícios que mais favoreceram para este resultado foram as aposentadorias por tempo de contribuição e por idade, que apresentaram, respectivamente, um aumento de $142,7 \%$ e $104,1 \%$.

10 Considero que, como não foi reduzida as disparidades entre as regióes e intrarregióes, de fato, no Brasil, especialmente, na regiáo Nordeste, não ocorreu uma intervençáo de caráter estrutural. 
Gráfico 1 - Evolução da Quantidade de Benefícios Emitidos pela Previdência Social Posição em dezembro

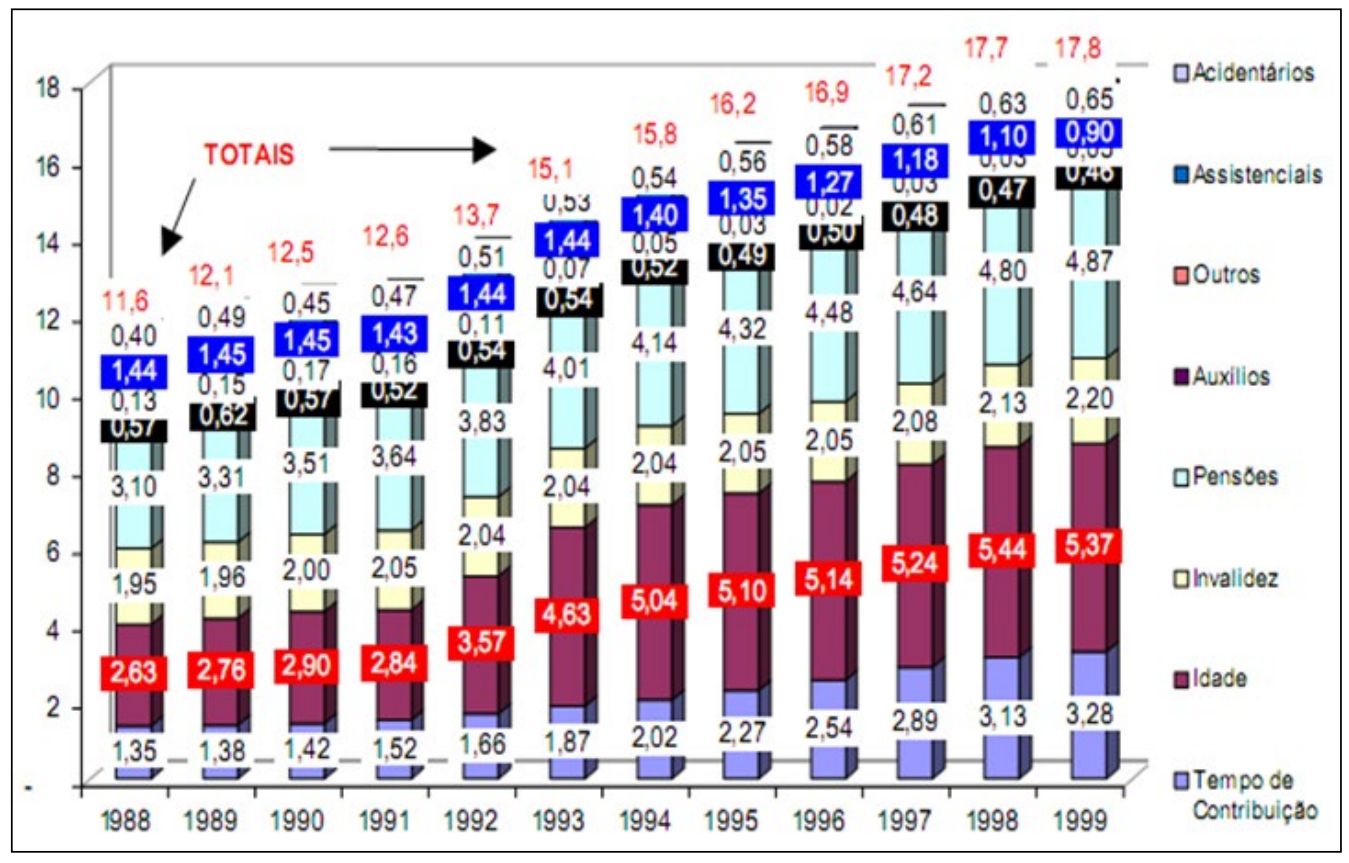

Fonte: Ministério da Previdência Social do Brasil (2000, p. 87).

Elaboração: Secretaria de Previdência Social.

Obs: De 1996 a 1999, exclusive a Lei Orgânica de Assistência Social (LOAS).

No que se refere à aposentadoria por idade, no Brasil, como explica Pinheiro (2000), tem como alvo a população com condições de formalização no trabalho mais precária, isto é, aqueles indivíduos sujeitos a alta rotatividade ${ }^{11}$, que contribuem esporadicamente para o sistema previdenciário e assim, acabam por não ter uma trajetória de rendimentos estável. Desse modo, esse tipo de benefício favorece, principalmente, a populaçáo com menores rendimentos, o que está relacionado a piores condiçōes de formalização laboral.

Além disso, Pinheiro (2000) também destaca que a aposentadoria por idade é o principal benefício concedido na zona rural, com baixa ou nenhuma contribuição por parte do beneficiário. Conforme observamos na Tabela 1, até 1991 não há nenhuma aposentadoria por tempo de contribuição concedida na área rural, sendo, o ano de 1992

11 A rotatividade no mercado de trabalho caracteriza-se pela situação aonde o trabalhador não consegue vínculos duradouros. Elementos que influenciam esta situação são diversos, tais quais a escolaridade baixa, setor de trabalho com alto grau de informalidade e região com menor desenvolvimento produtivo. Como estas situaçóes muitas vezes são pertencentes ao meio rural vinculado a agricultura familiar (sem um vínculo empregatício direto) ou mesmo ao processo de produção remunerado por participação na produção (Meia; terça) a aposentadoria por idade acaba sendo um elemento fundamental para esta população, já que a contribuição, voluntária ou via mercado formal está pouco acessível a este conjunto de trabalhadores. 
o início da concessão deste tipo de aposentadoria na área rural, tendo sido concedidas 62 aposentadorias desta espécie no referido ano.

Tabela 1- Quantidade de aposentadorias rurais concedidas, segundo os grupos de espécies - 1988/1999

\begin{tabular}{c|c|c|c|c}
\hline \multirow{2}{*}{ ANOS } & \multicolumn{4}{|c}{ GRUPOS DE ESPECIES DE APOSENTADORIA } \\
\cline { 2 - 5 } & $\begin{array}{c}\text { TEMPO DE } \\
\text { CONTRIBUIÇÁO }\end{array}$ & IDADE & INVALIDEZ & TOTAL \\
\hline 1988 & 00 & 32.030 & 23.944 & 155.974 \\
\hline 1989 & 00 & 134.146 & 21.241 & 155.387 \\
\hline 1990 & 00 & 152.291 & 21.164 & 173.455 \\
\hline 1991 & 00 & 129.449 & 11.249 & 140.698 \\
\hline 1992 & 62 & 670.089 & 9.225 & 679.376 \\
\hline 1993 & 205 & 919.839 & 16.334 & 936.378 \\
\hline 1994 & 308 & 421.530 & 13.582 & 435.420 \\
\hline 1995 & 644 & 120.706 & 11.971 & 133.321 \\
\hline 1996 & 964 & 134.589 & 12.875 & 148.428 \\
\hline 1997 & 1.179 & 198.632 & 17.170 & 216.981 \\
\hline 1998 & 1.200 & 294.458 & 18.537 & 314.195 \\
\hline 1999 & 815 & 310.858 & 22.320 & 333.993 \\
\hline
\end{tabular}

Fonte: Elaboração própria a partir dos dados do Anuário Estatístico da Previdência Social:

Suplemento Histórico (1980 a 2011) - AEPS 2011.

Quando se faz a comparação das três espécies de aposentadoria (tempo de contribuição, idade e invalidez), verifica-se que há uma trajetória crescente e expressiva do número de benefícios concedidos por idade, ou seja, sem nenhuma (ou pouca) contrapartida de contribuição. Desse modo, ao passo que, em 1988, foram concedidas 32.030 aposentadorias por idade e 23.944 por invalidez e nenhuma aposentadoria por tempo de contribuição; dez anos depois, observa-se a concessão de 1200 aposentadorias por tempo de contribuição e, 198.632 e 17.170 aposentadorias rurais por idade e invalidez, respectivamente (TABELA 1 ).

No que tange à concessão de benefícios previdenciários aos idosos da zona rural, como ressalta Delgado e Cardoso Júnior (2000), ocorreu em uma circunstância histórica muito peculiar, na qual, o próprio setor rural se descapitalizava e empobrecia. Nesse sentido, segundo os dados do Brasil (2001), entre 1991 e 1998, praticamente dobra o número absoluto de benefícios por idade acumulados no sistema rural, enquanto seu valor unitário passa de US\$ 44,1 mensais para US\$ 108,5. Ou seja, o impacto dessa reforma (de inclusão do homem do campo na concessão de aposentadoria independente da capacidade contributiva para o sistema) resultou na quadruplicação do gasto mensal com benefícios 
permanentes (como aposentadorias e pensóes), que cresceu de US\$ 180 milhóes em 1991, para aproximadamente US\$ 750 milhôes em 1998.

Ao analisar dados mais recentes, na comparação entre as aposentadorias rurais concedidas no Brasil e Nordeste, conforme observa-se na Tabela 1, do total de aposentadorias rurais concedidas pelo Ministério da Previdência no Brasil: 48,77\%; 48,89\%; 49,20\%; 48,64\% e 48,95\% nos anos de 2011, 2012, 2013, 2014 e 2015, respectivamente; são destinadas para a Região Nordeste. Ademais, verifica-se a redução, desde 2013, das concessóes de aposentadorias rurais, quando analisamos o Brasil e o Nordeste.

Aqui cabe comparar o Nordeste, também com a região Sul, devido ser essa, a segunda região com maior número de agricultura familiar. Desse modo, analisando a quantidade total de aposentadorias rurais concedidas na regiâo Sul, percebe-se que, em termos absolutos, foi bem aquém do que foi concedido à região Nordeste nos anos de 2011 à 2015. Por exemplo, em 2011, na regiáo Sul, foram concedidas 49.606 aposentadorias rurais, ao passo que, no Nordeste, foram concedidas 179.646 aposentadorias rurais. Em termos percentuais, em 2011, a regiáo Sul recebeu cerca de $27 \%$ do quantitativo de aposentadorias concedidas, nesse ano à região Nordeste (TABELA 2).

Por seu turno, quando comparamos a quantidade de aposentadorias rurais concedidas, entre o Brasil e o Sul, percebemos que, em 2011, do total de aposentadorias rurais concedidas no Brasil, 13,47\% foram destinadas para a região Sul, em 2012 (12,92\%), em 2013 (12,81\%), em 2014 (13,25\%) e em 2015 (13,77\%).

Por sua vez, verifica-se que, tanto no âmbito do Brasil, como da região Nordeste e da região Sul, a quantidade de aposentadorias rurais concedidas por tempo de contribuição é ínfima em relação às concedidas por idade. Por exemplo, em 2015, foram concedidas, no Brasil, 1.464 aposentadorias rurais por tempo de contribuição, ao passo que, foram concedidas, respectivamente: 286.676 e 23.134 aposentadorias rurais por idade e invalidez. Por sua vez, em 2015, na região Nordeste e Sul, foram concedidas, respectivamente: 401 e 258 (por tempo de contribuição); 141.305 e 38.488 (por idade) e 10.690 e 4.123 (por invalidez) (TABELA 3).

Tabela 2 - Quantidade total de aposentadorias rurais concedidas, comparação entre Brasil, Nordeste e Sul- 2011/2015

\begin{tabular}{c|c|c|c|c|c}
\hline \multirow{2}{*}{ ANOS } & \multicolumn{4}{|c}{ TOTAL } \\
\cline { 2 - 6 } & BRASIL & \multicolumn{2}{|c}{ NORDESTE } & \multicolumn{2}{c}{ SUL } \\
\hline 2011 & 368.314 & 179.646 & $48,77 \%$ & 49.606 & $13,47 \%$ \\
\hline 2012 & 377.114 & 184.397 & $48,89 \%$ & 48.716 & $12,92 \%$ \\
\hline 2013 & 386.673 & 190.272 & $49,20 \%$ & 49.521 & $12,81 \%$ \\
\hline 2014 & 366.208 & 178.119 & $48,64 \%$ & 48.536 & $13,25 \%$ \\
\hline 2015 & 311.274 & 152.396 & $48,95 \%$ & 42.869 & $13,77 \%$ \\
\hline
\end{tabular}

Fonte: Elaboraçáo própria a partir dos dados dos anuários estatísticos do ministério da previdência do Brasil (2013; 2016). 
Tabela 3 - Quantidade de aposentadorias rurais concedidas por grupos de espécies, comparação entre Brasil, Nordeste e Sul- 2011/2015

\begin{tabular}{|c|c|c|c|c|c|c|c|c|c|}
\hline \multirow{3}{*}{ ANOS } & \multicolumn{9}{|c|}{ GRUPOS DE ESPÉCIES } \\
\hline & \multicolumn{3}{|c|}{$\begin{array}{c}\text { TEMPO DE } \\
\text { CONTRIBUIÇÃO }\end{array}$} & \multicolumn{3}{|c|}{ IDADE } & \multicolumn{3}{|c|}{ INVALIDEZ } \\
\hline & BRA & NE & SUL & BRA & NE & SUL & BRA & NE & SUL \\
\hline 2011 & 1.338 & 300 & 259 & 343.052 & 168.046 & 43.424 & 23.924 & 11.300 & 5.923 \\
\hline 2012 & 1.228 & 262 & 252 & 352.000 & 172.774 & 43.001 & 23.886 & 11.361 & 5.463 \\
\hline 2013 & 1.402 & 371 & 257 & 358.620 & 177.484 & 43.541 & 26.651 & 12.417 & 5.723 \\
\hline 2014 & 1.447 & 453 & 264 & 337.861 & 164.852 & 43.173 & 26.900 & 12.814 & 5.099 \\
\hline 2015 & 1.464 & 401 & 258 & 286.676 & 141.305 & 38.488 & 23.134 & 10.690 & 4.123 \\
\hline
\end{tabular}

Fonte: Elaboração própria a partir dos dados dos anuários estatísticos do Ministério da Previdência do Brasil (2013; 2016).

Tais dados revelam a importância da previdência para o rural do Nordeste, ao passo que, por outro lado, pode ratificar a tese dos que defendem que a concessão expressiva de aposentadorias por idade, no Brasil, especialmente, na região Nordeste, expressa uma característica da insustentabilidade financeira, a longo prazo, do sistema de previdência social brasileiro. Ou seja, alega-se que as aposentadorias rurais sugam os recursos das contribuiçóes urbanas, em função de, na maioria das vezes, haver a concessão de aposentadorias por idade, sem ter ocorrido a contrapartida da contribuição (MIRANDA, 2010).

Entretanto, é importante lembrar que, os pressupostos daqueles que mais defendem essa tese, os neoliberais, segundo os quais, os contribuintes devem ser os únicos responsáveis pela formação de seus benefícios futuros, contradiz o princípio básico do regime de repartição vigente no Brasil. Logo, para que tais alegações tivessem sustentação, teríamos de estar incluídos no regime de capitalização, modelo este, em que o valor das contribuiçóes se refletem diretamente no valor dos benefícios auferidos pelos inativos. Ademais, tal alegação não supõe a participação do Estado, como é preconizada na Constituição de 1988.

E mais, quando falamos de Previdência no Brasil, não devemos nos esquecer da sua concepção ideológica, definida constitucionalmente; ou seja, não devemos nos esquecer que ela é financiada pelo tripé: contribuintes, empregadores e Estado, e, isso, não revela uma fragilidade, mas sim, proporciona uma solidez ao sistema, principalmente, em períodos de crise quando a massa salarial cai e, por conseguinte, as contribuiçóes dos empregados; como discutimos no bloco teórico.

Portanto, devemos ter em mente que a questão não é que as aposentadorias rurais por idade sugam os recursos das contribuiçóes urbanas, pois, há outras fontes de receitas, que são próprias e oriundas da tributação.

Ademais, devemos ter em mente, que a Previdência como um sistema que foi concebido para proporcionar a proteçáo àqueles que perdem a capacidade laboral, no que tange aos moradores do rural, a aposentadoria rural por idade, foi concedida pelo 
Governo Brasileiro, como um instrumento compensatório, isto é, vista como a solução para os agricultores que não conseguiam se modernizar tecnologicamente nem se integrar ao conjunto da economia através da indústria, comércio e serviços. Assim, a maior parte das aposentadorias rurais concedidas está na faixa de um salário mínimo, se apresentado como um instrumento de desenvolvimento rural, dando possibilidades de subsistência para aqueles que possuem um trabalho baseado na sazonalidade.

Nesse sentido, de modo geral, quando voltamos à análise para os montantes dos valores das aposentadorias concedidas para o rural e para o urbano, constatamos uma grande disparidade. Ou seja, quando observamos a Tabela 2, verificamos, que, o valor médio das aposentadorias rurais por tempo de contribuição é de: R\$ 794,57 (em 2013); R\$ 827,91 (em 2014); R\$943,30 (em 2015). Ao passo que a média das aposentadorias rurais por idade é de: $\mathrm{R} \$$ 679,54 (em 2013); R\$ 726,12 (em 2014) e $\mathrm{R} \$ 790,68$ (em 2015). Em outros termos, para o beneficiário, em média, não difere, tão substancialmente, se aposentar por tempo de contribuição ou por idade. Valores superiores aos do salário mínimo.

Por outro lado, observando os dados do Brasil (2013; 2016), verificamos, que, o valor médio das aposentadorias urbanas por tempo de contribuição é de: R $\$ 1.635,82$ (em 2013); $\mathrm{R} \$ 1.740,29$ (em 2014); $\mathrm{R} \$ 2.001,03$ (em 2015). Ao passo que a média das aposentadorias urbanas por idade é de: $\mathrm{R} \$ 932,15$ (em 2013); $\mathrm{R} \$ 997,01$ (em 2014) e $\mathrm{R} \$$ $1.099,85$ (em 2015). Portanto, para todos os anos, os benefícios médios urbanos foram superiores aos benefícios médios da zona urbana.

Ademais, na comparação entre os valores concedidos por grupos de espécies nas zonas urbana e rural percebe-se que os valores absolutos destinados aos pagamentos de aposentadorias por tempo de contribuição da zona urbana foram superiores aos da zona rural, para os anos analisados. Por exemplo, em 2015, enquanto foi direcionado $\mathrm{R} \$ 638$ milhôes para pagar as aposentadorias urbanas por contribuição concedidas neste ano; na zona rural foi de $\mathrm{R} \$ 1.381$ milhóes (TABELA 4).

Tabela 4 - Valor de aposentadorias urbanas e rurais concedidas, por grupos de espécies, no Brasil - 2011/2015

\begin{tabular}{c|c|c|c|c}
\hline \multirow{2}{*}{ ANOS } & \multicolumn{4}{|c}{ Valor (R\$ Mil) } \\
\cline { 2 - 5 } & \multicolumn{4}{|c}{ URBANO } \\
\cline { 2 - 5 } & \begin{tabular}{c} 
GEMPO DE \\
\cline { 2 - 5 }
\end{tabular} & IDADE DE ESPECIES & INVALIDEZ & TOTAL \\
\hline $\mathbf{2 0 1 1}$ & 411.651 & 186.596 & 159.699 & 757.946 \\
\hline $\mathbf{2 0 1 2}$ & 444.777 & 231.858 & 172.609 & 849.243 \\
\hline $\mathbf{2 0 1 3}$ & 511.781 & 275.826 & 191.943 & 979.549 \\
\hline $\mathbf{2 0 1 4}$ & 546.618 & 306.908 & 195.924 & 1.049 .451 \\
\hline $\mathbf{2 0 1 5}$ & 638.321 & 318.038 & 177.808 & 1.134 .167 \\
\hline
\end{tabular}




\begin{tabular}{c|c|c|c|c}
\hline \multirow{2}{*}{ ANOS } & \multicolumn{4}{|c}{ RURAL } \\
\cline { 2 - 5 } & $\begin{array}{c}\text { TEMPO DE } \\
\text { CONTRIBUIÇÃO }\end{array}$ & IDADE & INVALIDEZ & TOTAL \\
\hline \multirow{2}{*}{$\mathbf{2 0 1 1}$} & 890 & 187.219 & 13.132 & 201.240 \\
\hline $\mathbf{2 0 1 2}$ & 900 & 219.484 & 14.916 & 235.301 \\
\hline $\mathbf{2 0 1 3}$ & 1.114 & 243.698 & 18.125 & 262.937 \\
\hline $\mathbf{2 0 1 4}$ & 1.198 & 245.330 & 19.544 & 266.072 \\
\hline $\mathbf{2 0 1 5}$ & 1.381 & 226.671 & 18.290 & 246.342 \\
\hline
\end{tabular}

Fonte: Elaboração Própria a partir dos dados dos anuários estatísticos do ministério da previdência de Brasil (2013; 2016).

Em 2015, conforme Brasil (2016), 99,4\% dos benefícios concedidos aos moradores do rural apresentavam valor de até um piso previdenciário, ao passo que os benefícios dos moradores da zona urbana dessa faixa corresponderam a 41,9\% do total. Destaca-se, também, que 98,2\% dos benefícios urbanos estavam contidos na faixa que atinge até cinco pisos previdenciários.

No âmbito do Nordeste, quando comparamos com os valores nacionais destinados a concessão de novas aposentadorias urbanas e rurais, nos anos de 2013 à 2015, observamos que foram destinados: 10,99\%; no ano de 2013; 11,6\% (2014) e 11,4\% (2015) para aposentadorias urbanas por tempo de contribuição. Por sua vez, para aposentadorias por idade foram destinados 14,48\% (2013); 14,13\% (2014) e 14,42\% (2015).

Para os mesmos anos, quando nos debruçamos na análise dos valores de aposentadorias rurais concedidas para o Nordeste na comparação com o Brasil, verificamos que: 23,07\% dos valores destinados para as aposentadorias rurais por contribuição no Brasil, foram direcionadas para o Nordeste no ano de 2013; ao passo que, em 2014 e 2015, foram destinados: $28 \%$ e $23,5 \%$; respectivamente.

No que tange à aposentadoria rural por idade: 49,4\% (em 2013); 48,7\% (em 2014) e 49\% (em 2015) dos valores nacionais destinados para o pagamento de aposentadorias rurais nessa espécie foram para o Nordeste.

Ainda no que se refere à aposentadoria por idade, é importante considerar que, no Brasil, beneficiou àqueles indivíduos sujeitos à alta rotatividade, que contribuem esporadicamente para o sistema previdenciário e assim, acabam por não terem uma trajetória de rendimentos estável. Favorecendo, principalmente, a população com menores rendimentos, o que está relacionado a piores condiçôes de formalização laboral e menores anos de escolaridade. (PINHEIRO, 2000; DELGADO, 2000). Em outras palavras, como destaca estudo do CONTAG (2016, p.89): "são responsáveis pela diminuição da pobreza em idade avançada e pelo sustento de um grande número de famílias que têm nesses idosos uma importante e estável fonte de renda”.

Por outro lado, foi percebido que o benefício rural cumpre não só a função precípua de seguro previdenciário, mas também atende de modo fundamental, ainda 
que, indiretamente, uma função que se aproxima de um seguro agrícola (de minimizar ou desonerar o produtor rural dos altos riscos que inibem a atividade produtiva rural), uma vez que serve para reprogramar e aumentar o potencial produtivo da economia familiar, ou seja, garante a subsistência familiar e até permite financiar a pequena produção das unidades familiares. Inclusive, como observado, em 1998; 44,7\% dos domicílios responsáveis por estabelecimento rural no Sul e 51,5\% no Nordeste utilizaram a renda do benefício previdenciário na manutenção e custeio das suas atividades produtivas ${ }^{12}$ (DELGADO, 2000).

Em síntese, verifica-se que para os conservadores, os benefícios concedidos devem fazer jus às contribuiçóes realizadas ao longo da vida laboral pelo indivíduo, reduzindo ao máximo os subsídios que não têm caráter de amparo social. Contudo, vale ressaltar que isto não quer dizer, necessariamente, que há de se realizar uma migração para o sistema de capitalização, mas sim, conforme essa linha ideológica, o sistema deverá realizar um balanço financeiro para que o Estado brasileiro não gaste em demasia com a Previdência Social, para que não se veja obrigado a deixar em segundo plano outros gastos que seriam mais importantes na concepção destes estudiosos, como: em infraestrutura, educação e segurança pública (MIRANDA, 2010).

Entretanto, é importante ressaltar que o regime de repartiçáo simples se torna extremamente dependente dos ciclos econômicos. Assim, como argumentam os conservadores, geralmente em períodos de expansão se tem uma elevação do nível de empregos formais (o que é bom para o sistema: consequentemente, elevando o número de contribuintes e a receita previdenciária), ocorrendo o inverso em períodos de crise. Como se sabe, no Brasil o trabalho informal é bastante expressivo, agravando a situaçáa, e com isso, exigindo que se crie mais postos de trabalho formal. Contudo, vale lembrar, que a constituiçâoo de 1988 inovou ao reduzir a dependência da receita previdenciária às oscilaçóes do ciclo econômico, estabelecendo a tributação sobre o faturamento e o lucro, porque são bases de cálculo mais estáveis para as contribuiçôes sociais que a folha salarial.

Ademais, como ressalta Delgado e Cardoso Júnior (2000), como resultado de suas pesquisas (que foram publicadas pelo Ministério da Previdência Social do Brasil), foi percebido que o benefício rural cumpre não só a função precípua de seguro previdenciário, isto é, operando dentro do âmbito original que orientou sua concepção, mas também atende de modo fundamental, ainda que indiretamente, uma funçáo que se aproxima de um seguro agrícola, uma vez que serve para reprogramar e aumentar o potencial produtivo da economia familiar, ou seja, garante a subsistência familiar e até permite financiar a pequena produçấo das unidades familiares. Neste sentido percebe-se que a previdência cumpre com o seu papel, conforme destacado no bloco teórico.

Por sua vez, segundo a pesquisa de avaliação socioeconômica e regional da Previdência Rural, divulgada pelo Brasil (2001), no estudo que verifica a efetividade da política pública

12 Mais detalhes, ver os estudos de Delgado (2000), Pinheiro (2000) e Contag (2016). Particularmente, a pesquisa de Delgado (2000) apresenta dados e análises, fruto de estudo de campo, de todas as regióes do Brasil. 
de acesso à aposentadoria rural nos primeiros anos de sua existência, quando se analisa os dados da relação dos domicílios com a atividade econômica, verifica-se que $48 \%$ dos domicílios da Região Sul e 43\% dos domicílios do Nordeste eram responsáveis, no final da década de 1990, por estabelecimento rural ativo. A agricultura é a atividade predominante em $72 \%$ dos domicílios pesquisados no Sul e em cerca de $85 \%$ no Nordeste.

Ademais, cabe destacar que $44,7 \%$ dos domicílios responsáveis por estabelecimento rural no Sul e 51,5\% no Nordeste utilizaram a renda do benefício previdenciário na manutenção e custeio das suas atividades produtivas. Por outro lado, apenas 3,9\% dos domicílios responsáveis por estabelecimento rural se declararam inativos no Sul, enquanto que no Nordeste este percentual representou 6,5\%.

Enfim, como bem resume Delgado e Cardoso Júnior (2000, p.184):

Seja operando meramente como seguro de renda vitalícia, situação na qual o benefício responde por praticamente toda a renda domiciliar, seja servindo também como seguro agrícola, onde aparece como fundamental nas estratégias de ampliação da renda rural, ou meramente viabilizando a geração de uma renda extra de subsistência, cabe ressaltar a importância das relaçóes existentes entre as unidades familiares beneficiárias da Previdência Rural e as atividades econômicas a sua volta.

E mais, quando se verifica alguns outros estudos apresentados pelo Ministério da Previdência Social do Brasil, analisando a década de 1990, este, chegou a conclusão que a redução dos níveis de pobreza durante a década de 90 ocorreu, fundamentalmente, a partir da combinação da estabilização econômica com o aumento das transferências de recursos da Previdência Social.

Assim, para demonstrar o efeito da Previdência sobre a redução da pobreza, pode-se verificar no Gráfico 2, o resultado de um estudo baseado nos dados da Pesquisa Nacional por Amostra de Domicílios- PNAD/IBGE, demonstrando qual seria o nível de pobreza no País, no período de 1992 a 2014, e como seria a evolução deste, caso não existissem as transferências da Previdência Social.

Em termos gerais, de acordo com os resultados apresentados no Gráfico 2, a distância entre as duas linhas evidencia o impacto crescente da Previdência sobre a pobreza no período de 1992 a 2014. Por exemplo, em 1993 constata-se que o nível de pobreza com transferências da Previdência é de 62,5\%, já sem as transferências é de 67,9\%. Tal fato só foi possível em razão da expansão da política previdenciária que serviu de amortecedor da crise econômica da "década perdida" (década de 1980). Por sua vez, entre 1993 e 1995 , percebe-se o efeito da estabilização de preços sobre a redução da pobreza, onde, o aumento do poder aquisitivo dos mais pobres possibilitou a diminuição de 10,1 pontos percentuais no nível de pobreza nesses dois anos.

No período pós-Plano Real, entre 1995 e 1997, a pobreza permaneceu estabilizada em patamares que oscilaram entre 52,4\% e 51,8\%. Em 2003, excluindo-se as transferências feitas por meio do sistema previdenciário, o percentual de pobres aumentaria de 52,9\% para $63,1 \%$. Por fim, em 2014, o nível de pobreza atingiu 24,2\% com transferência previdenciária e $37,6 \%$, sem transferência previdência. 
Estes dados relacionam de forma direta o percentual de pobres no período 19922014, mostrando uma nítida redução deste quando o foco da atuação governamental tem nele objetivo. Percebe-se que a redução dos pobres se dá tanto naquele grupo que recebe a transferência previdenciária como para aquele que não a recebe, ocorrendo, contudo de forma mais intensa no grupo que a recebe, o que reforça sua importância e seu papel social. O que se apreende desta discussão é que, o estado possui força e instrumentos múltiplos para combater a desigualdade de renda e que quando esta passa a ser um de seus objetivos, como era expressamente divulgado dentro dos governos Lula e Dilma, bons resultados podem ser alcançados.

Gráfico 2 - Percentual de pobres no Brasil, com e sem as transferências previdenciárias (\%) - 1992 a 2014/ Linha de Pobreza = 1/2 Salário Mínimo de set/2014 (INPC)

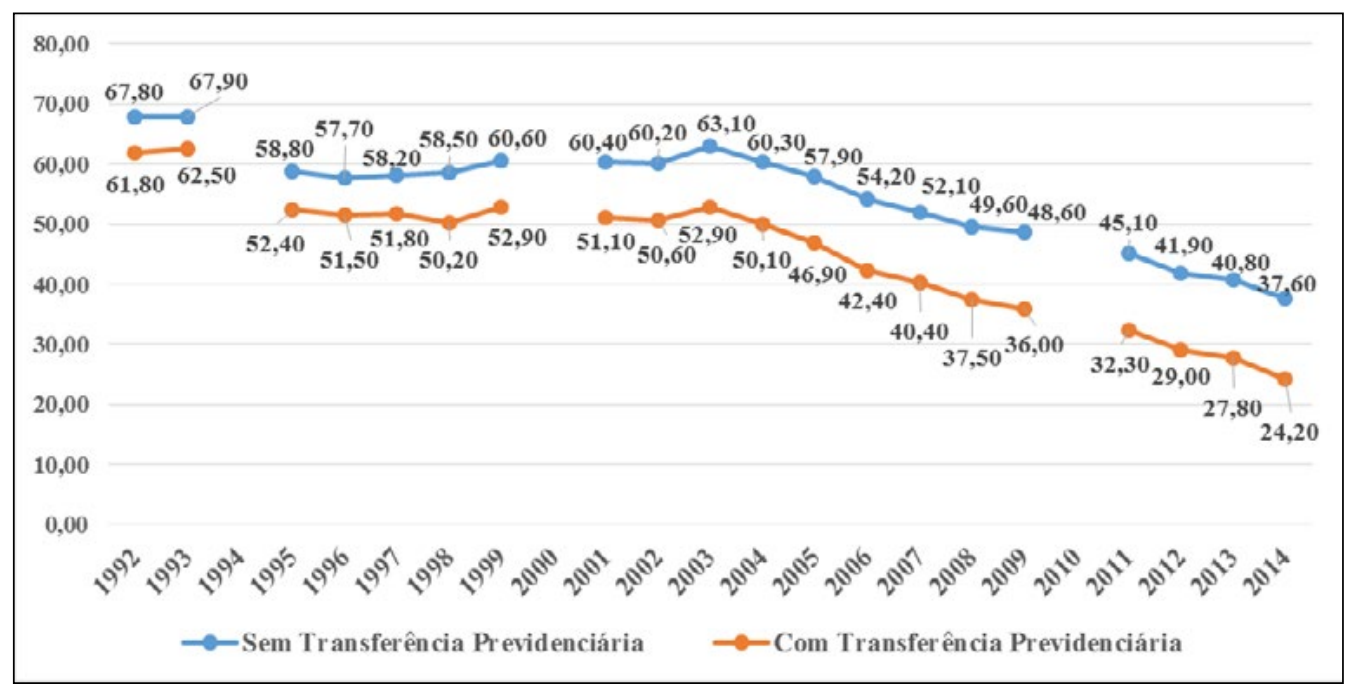

Fonte: Elaboração Própria a partir dos dados do IBGE/PNADs harmonizada, excluindo área rural da Região Norte, salvo Tocantins.

Além disso, como já destaca Brasil (2001, p.4) em estudo semelhante, mas analisando a década de 1990: "[...] esse papel social do sistema previdenciário tem sido fortalecido, seja para amortecer de forma anticíclica o impacto de crises econômicas, seja para contribuir para o círculo virtuoso do crescimento da economia com estabilidade social e política”.

Cabe destacar que, nos anos após 2003, no governo LULA, a política de valorização do Salário Mínimo (SM) tem ganhado espaço na política nacional, em decorrência de uma política de reajustes com ganhos reais, elevando o seu poder de compra e a transferência de renda. Em suma, destaca-se que o crescimento permanente do salário mínimo tem se apresentado como instrumento de redistribuição de renda, não só como elemento de valorização do trabalho, mas como renda substituta do trabalho (CONTAG, 2016).

Tal argumento é sustentado, quando se considera que a maioria dos benefícios emitidos pela previdência foi no valor do salário mínimo $(64,4 \%$, se considerarmos somente o RGPS) em dezembro de 2015. No segmento urbano, em dezembro de 2015, representou 
$47,3 \%$ do total efetivamente pago, e, no meio rural, quase o total dos benefícios. Ademais, destaca-se que a previdência se apresenta mais importante para os municípios do Nordeste do que o Fundo de Participaçáo dos Municípios (FPM), como explica a CONTAG (2016, p.10):

\begin{abstract}
De acordo com o levantamento feito em 2011, em 3.774 municípios brasileiros, os repasses da Previdência superavam os do FPM - o que representa quase $68 \%$ do total de cidades do Brasil. A região com mais municípios nessa situação é a Sul: 74,16\% das cidades recebem mais recursos do INSS do que do FPM. Em seguida, vem a região Sudeste, com 73,50\%; Nordeste, com 66\%; Centro-Oeste, com 56,87\%; e Norte, com 48,55\%.
\end{abstract}

Enfim, após a promulgação da Constituição de 1988, analisando-se alguns dados da década de 1990, como frisa Pinheiro (2000), em meio às condiçóes adversas da economia brasileira, com baixos índices de crescimento e diante das profundas alteraçóes no mercado de trabalho, em especial, com o aumento da informalidade; as transferências de recursos previdenciários passaram a ter um papel fundamental de garantia de renda (com impactos no combate à pobreza e melhoria na distribuição de renda), tanto para o beneficiário, quanto para os seus familiares. E analisando o cenário mais recente, a política de valorizaçáo do salário mínimo contribuiu para a valorização das aposentadorias, uma vez que, desde 2003, as aposentadorias são corrigidas de acordo com o aumento do salário mínimo.

De modo geral, são inúmeros os benefícios socioeconômicos para o Brasil, e em especial, para o Nordeste rural, promovidos pela previdência. Debater esses dados/ informações e análises é crucial antes da realização de colocar nas "costas" dos aposentados rurais uma parte da "culpa" da insustentabilidade financeira do sistema previdenciário brasileiro.

\title{
5 CONSIDERAÇÓES FINAIS
}

A partir das formulaçōes teóricas apresentadas e de indicadores numéricos conclui-se que a importância socioeconômica da aposentadoria rural reside no fato de reduzir o nível de pobreza e desigualdade de renda da regiáo, mas também, serve como um seguro agrícola.

Vimos que segundo o último estudo realizado pelo Ministério da Previdência Social, no final da década de 1990, no âmbito do rural, a agricultura era a atividade predominante em $72 \%$ dos domicílios pesquisados no Sul e em cerca de $85 \%$ no Nordeste. E dentro desse cenário; $44,7 \%$ dos domicílios responsáveis por estabelecimento rural no Sul e 51,5\% no Nordeste, utilizaram a renda do benefício previdenciário na manutenção e custeio das suas atividades produtivas. Embora, não tenha sido realizado, pelo Ministério da Previdência Social, para os anos recentes, um estudo semelhante no âmbito da região Nordeste; apenas tendo sido feitos estudos em municípios específicos, tais dados expressam a importância para o Nordeste, em especial para o rural, da previdência já no período posterior a promulgação da Constituição de 1988.

Também se verificou que, a previdência é mais importante para a maioria dos municípios do Nordeste do que o Fundo de Participação dos Municípios. Por exemplo, em 2011, em 3.774 municípios brasileiros, os repasses da Previdência superavam os do 
Fundo de Participação dos Munícipios em quase 68\% do total de cidades do Brasil. E, curiosamente, da região Sul, $74,16 \%$ das cidades receberam mais recursos do INSS do que do FPM. Em seguida, vem a região Sudeste, com 73,50\%; e, após a regiáo Nordeste, com $66 \%$ das suas cidades receberam mais recursos do INSS do que do FPM.

$\mathrm{Na}$ conjuntura atual nacional e internacional de crises econômicas, na qual, defendese a necessidade imediata de reformas nas políticas sociais, é essencial compreender melhor sobre a Previdência Social Brasileira, inclusive, não considerá-la isoladamente, mas sim, como parte da seguridade social, como preconiza a Constituição Federal de 1988.

No que se refere à concessão de aposentadoria rural no Brasil, observou-se que nos anos recentes de 2011, 2012, 2013, 2014 e 2015, do total de aposentadorias concedidas pelo RGPS, enquanto menos de $14 \%$ foram para o rural do Sul, a grande maioria: quase $50 \%$ foram para o rural do Nordeste, sendo que, a maioria das aposentadorias são da categoria aposentadoria por idade. Isso significa a importância da política de concessão de aposentadoria por idade a partir dos anos de 1990. E mais, vimos que, a aposentadoria por idade beneficia àqueles indivíduos sujeitos à alta rotatividade, que contribuem esporadicamente para o sistema previdenciário e assim, acabam por não terem uma trajetória de rendimentos estável. Portanto, isso acaba por favorecer principalmente, a população com menores rendimentos, o que está relacionado a piores condiçóes de formalização laboral.

Vale salientar que este trabalho apresenta uma temática de extrema importância para a sociedade Brasileira, principalmente no cenário recente de crises políticas, econômicas e, acima de tudo, moral. Desse modo, em meio a tentativa, a todo custo, de uma reforma previdenciária, dedicar atenção para os efeitos da introdução da aposentadoria por idade para a agricultura familiar é imprescindível, para desmistificar os discursos falaciosos que têm emergido e, de fato, trazer uma reflexão se a prioridade do Estado deva ser a eficiência econômica às custas dos mais vulneráveis da sociedade ou uma equidade econômica que preza pela dignidade humana.

Portanto, deve-se assinalar que a previdência não deve ser resumida a um entendimento meramente financeiro. É necessário analisar a Previdência com um olhar multifacetado, pois não se pode esquecer que é um mecanismo para assegurar qualidade de vida àqueles que perderam ou reduziram sua capacidade laboral (por idade, doença, invalidez) e que estão cansados da lida árdua sob o sol quente. $\mathrm{O}$ caminho de concessão de direitos para o rural foi longo e comedido, devemos refletir sobre a temática da previdência para não retrocedermos, portanto, esse trabalho é o início de algumas reflexóes, sendo ampla e complexa a temática ora tratada, não comportando aqui neste espaço.

Por fim, para trabalhos futuros recomenda-se uma análise de dados da concessão de aposentadoria rural total e por categoria para as cinco regióes do Brasil e uma análise mais aprofundada da importância do Fundo de Participação dos Municípios em comparação com a importância da Previdência rural para todas as regióes do Brasil. Outro tema que daria outra pesquisa, mas que demanda um aporte expressivo de recursos, já que necessita ir a campo, seria atualizar o trabalho de Delgado e Cardoso Júnior (2000) e verificar o percentual de renda das famílias do rural do Brasil que vem da aposentadoria rural, de qual categoria e qual o percentual da aposentadoria que tem sido usado como seguro agrícola. Essa última recomendação de pesquisa é de extrema relevância, visto que o trabalho, dos 
autores supracitados, trouxe descobertas interessantes e que só têm sido confirmadas nos anos recentes em análises de estudos em lócus menores, como determinado estado ou cidade.

\section{REFERÊNCIAS}

BRASIL. Constituição (1988). Constituiçáo da República Federativa do Brasil. Brasília, DF: Senado Federal. Disponível em: <http://www.planalto.gov.br/ccivil_03/ constituicao/constituicao.htm>. Acesso em: jul. 2016.

. Ministério da Previdência Social. Anuário Estatístico da Previdência Social: Suplemento Histórico (1980 a 2011). Brasília: MPS/DATAPREV, 2013, ISSN 01048139. Disponível em: <http://www.previdencia.gov.br>. Acesso em: ago. 2016.

. Ministério da Previdência Social. Análise da Seguridade Social 2015. Brasília: ANFIP, agosto/2016, 16º ed. ISBN: 978-85-62102-22-6.

. Ministério da Previdência Social. Previdência, Inclusáo Social e Combate à Pobreza. Brasília, v. 13, n. 07, p. 1-20, jul. 2001. Disponível em: < http://www.mpas.gov. br/arquivos/office/3_081014--903.pdf104509>. Acesso em: jan. 2014.

CONTAG. Previdência Social Rural: potencialidades e desafios. Jul. 2016. Disponível em: <http://www.contag.org.br/arquivos/relatorio_previdencia\%202.pdf>. Acesso em: set. 2016.]

CUNHA, L. H.; PAULINO, J. S. Convivência com o semiárido: um novo paradigma para políticas públicas no Nordeste? In: NEVES, D. P.; GOMES, R. A.; LEAL, P. F. (Org.) Quadros e programas institucionais em políticas públicas. Campina Grande: EDUEPB, 2014. p. 27-58.

Da SILVA, D. M. O. B.; SCHMIDT FILHO, R.; AGUIAR, M. B. M.; COSTA, F. B. PRONAF: uma avaliação da Distribuição Regional dos contratos de crédito e seus impactos sobre o desenvolvimento rural do Nordeste Brasileiro. OKARA: Geografia em debate, v.11, n. 2, p. 376-396, 2017.

DELGADO, G. C.; CARDOSO JÚNIOR, J. C. Universalizaçâo de Direitos Sociais Mínimos no Brasil: o Caso da Previdência Rural nos Anos 90. In: Ministério da Previdência Social do Brasil. Coleçáo Previdência Social, série Debates: Previdência, Assistência Social e Combate à Pobreza. Brasília. MPAS, 2000, p. 173- 195.

FERREIRA, G. G. Condiçóes atuariais para a construçáo do fundo previdenciário federal - FUNPRESP. 2008. 84 f. Dissertação (Mestrado em Economia) - Faculdade de economia, administração e contabilidade, Universidade de São Paulo, São Paulo, 2008.

GENTIL, D. L. Política fiscal e falsa crise da Seguridade Social brasileira: análise financeira do período 1990-2005. 2006. Tese (Doutorado em Economia) - Instituto de 
Economia, Universidade Federal do Rio de Janeiro, Rio de Janeiro, 2006. Disponível em: <http://www.corecon-rj.org.br/ced/tese_previdencia_denise_lobato.pdf >. Acesso em: jul. de 2013.

- A política fiscal e a falsa crise do sistema de seguridade social no Brasil:

análise financeira do período recente. In: SICSÚ, João (Org.); Oliveira, Francisco de.

Arrecadação, de onde vem? Gastos Públicos, para onde vão?. São Paulo. Ed. Boitempo, 2007, p. 18-29.

GUIMARÁES, R. É. dos R. O trabalhador rural e a previdência social - evoluçáo histórica e aspectos controvertidos. Revista Virtual da AGU, Ano IX, n. 88, maio de 2009. Disponível em: < www.agu.gov.br/page/download/index/id/580103>. Aceso em: set. 2016.

GRISA, C.; Schneider, S. Três Geraçóes de Políticas Públicas para a Agricultura Familiar e formas de interaçáo entre sociedade e Estado no Brasil. Rev. Econ. Sociol. Rural [online]. 2015, vol.52, suppl.1, p.125-146. ISSN 0103-2003. Disponível em: < http://www.scielo.br/scielo.php?pid=S0103-20032014000600007\&script=sci_ abstract\&tlng=pt>. Acesso em: set. 2016.

LEÔNCIO, J. da S. Falácia de Déficits na Seguridade Social nos anos de 2009 e 2010. 2011. 74 f. Monografia (Graduação em Ciências Econômicas) - Unidade Acadêmica de Economia, Universidade Federal de Campina Grande, Campina Grande, 2011.

MARQUES, R. M. Uma Previdência Social para os brasileiros. In: SICSÚ, João (Org.); Oliveira, Francisco de. Arrecadaçáo, de onde vem? Gastos Públicos, para onde vão?. São Paulo. Ed. Boitempo, 2007, p. 17-28.

MIRANDA, A. L. F. O Déficit da Previdência Social: Análise comparativa entre as duas linhas metodológicas divergentes. 2010. 97 f. Monografia (Graduação em Ciências Econômicas) - Departamento de Ciências Econômicas, Universidade Federal de Santa Catarina, Florianópolis, 2010.

PASSARINHO, P. Previdência Social Pública: um serviço universal ao cidadão brasileiro. In: SICSÚ, João (Org.); Oliveira, Francisco de. Arrecadaçáo, de onde vem? Gastos

Públicos, para onde vão?. São Paulo. Ed. Boitempo, 2007, p. 37-50.

PETERSON, P. Agroecologia e a superação do paradigma da modernização. In: NIEDERLE, P. A.; ALMEIDA, L.; VEZZANI, F. M. Agroecologia: práticas, mercados e políticas para uma nova agricultura. Curitiba: Kairós, 2013. 393 p. ISBN no 978-8563806-16-1.

PINHEIRO, V. C. Aspectos Sociais da Previdência no Brasil: O Desafio de Aumentar a Cobertura. In: Ministério da Previdência Social do Brasil. Coleçáo Previdência Social, 
série Debates: Previdência, Assistência Social e Combate à Pobreza. Brasília. MPAS, 2000, p. 125- 152.

RAMOS, S. Y; MARTHA JUNIOR; G. B. Evolução da Política de Crédito Rural Brasileira. Planaltina: EMBRAPA Cerrados, 2010. (Documento 292).

SERRA E GURGEL, J. B. Evolução da Previdência Social. 2. ed. - Brasília: Studio9Comunicação, 2011. 368 p.

SCHNEIDER, S. Situando o desenvolvimento rural no Brasil: o contexto e as questóes em debate. Revista de Economia Política, v. 30, n. 3, p. 511-531, julho-setembro/2010.

SILVA, R. M. A. Entre o Combate à Seca e a Convivência com o Semi-Árido: transiçóes, paradigmas e sustentabilidade do desenvolvimento. 2006. 298 f. Tese (Doutorado em Desenvolvimento Sustentável) - Centro de Desenvolvimento Sustentável, Universidade de Brasília, Brasília, 2006.

TAVARES, M. C. Ajuste e reestruturação nos países centrais: A modernização conservadora. Economia e Sociedade, n. 1, agosto de 1992.

WANDERLEY, M.N.B. Raízes históricas do campesinato brasileiro. In: TEDESCO, J.C. (Org.). Agricultura familiar: realidades e perspectivas. $3^{\mathrm{a}} \mathrm{ed}$. Passo Fundo: EDIUPF, 2001. p. 21-55.

A sociologia rural na América Latina: produção de conhecimento e compromisso com a sociedade. ALASRU Nueva Época, 2010; p.17-44. 